Diane Sbardelotto

Mestranda

Programa de

em Educacacãa da

UFRGS. Licenciada

Bacharel em Artes

Visuais (UFRGS,

UNOCHAPECOO).

Artista visul

A

e professora

de

- Arte Corpo

Arte, Corpo,

Paola Zordan

Artista visual

professor do

Departamento de

Artes Visuais

do Programa de

Pós-graduação

em Educação da

UFRGS. Doutor

pela UFRGS

dos curso de

Licenciatura

Bacharelado em

Artes Visuais $d$

UFRGS. Líder do

Grupo de pesquis

ARCOE, Arte, Corpo

e EnSigno (CNPq)

articula o M.A.L.H.A

Movimento

Liberação de

Humores Artísticos.

\section{Hilda Hilst, fotodobragens e continuações do corpo de Hilda}

Hilst, photofolding and continuations of the Hilda body

Resumo: Em uma residência artística realizada em maio de 2017 na Casa do Sol onde viveu e trabalhou a escritora Hilda Hilst, produzilu-se trabalhos em arte que integram a pesquisa de Mestrado em Educação intitulada Fotodobragens para continuar o corpo, a qual articula o conceito deleuzo-foucaultiano de dobra em experimentações-continuidades do próprio corpo por meio de performances, fotografia e escrita. São feitas relações entre essa pesquisa acadêmico-poética em processo e o corpo na obra e na casa de Hilda Hilst, com enfoque em questões da subjetivação da mulher artista e nas práticas de si.

Palavras-chave: Fotodobragens; Hilda Hilst; Corpo; Dobra; Subjetivação.

Abstract: During an artist residency in May 2017 at the Casa do Sol, where the writer Hilda Hilst lived and worked, artworks were produced that are part of the Master' Research Project in Education entitled "Photofolding to continue the body" which articulates the Deleuzian-Foucauldian concept of the "fold" in experimentations-continuities of the body itself through performances, photography and writing. Here relations are made between this academic poetic research in progress and the body in the works and in Hilda Hilst's house, focusing on issues of the subjectification of

Key-words: Photofolding; Hilda Hilst; Body; Fold; Subjectivation..
.. e afinal é o corpo esse que não pode mais ser tocado, afinal ele existe, e eu poderia dizer que sou meu corpo? Se eu fosse meu corpo ele estaria velho assim? O que é a linguagem? linguagem para meu corpo: um funeral de mim... (HILST, 2002, p. 19).

corpo que aqui escreve começa a ser lido. Começa a ser lido o que escreve esse corpo. Escrever começa corpos. Ao escrever, os continuo. E continuo escrevendo. Continuar é não permanecer. Continuar um corpo é alterá-lo. Escrever performatiza corpos. Escrever pode movimentá-los, no tempo e espaço, na própria matéria de que são feitos. Ora por incompatibilidades entre linguagem e sentidos, por excesso, por falta, por imposições, estas também de linguagem, que deformam o corpo em violências da subjetivação. Ao escrever poderíamos, também, parar. Aqui, nessa pesquisa, feita de alternâncias entre inércia e movimento, é no sólido pausar da imagem fotografada que alguns deslocamentos do corpo são percebidos (Figura 1).

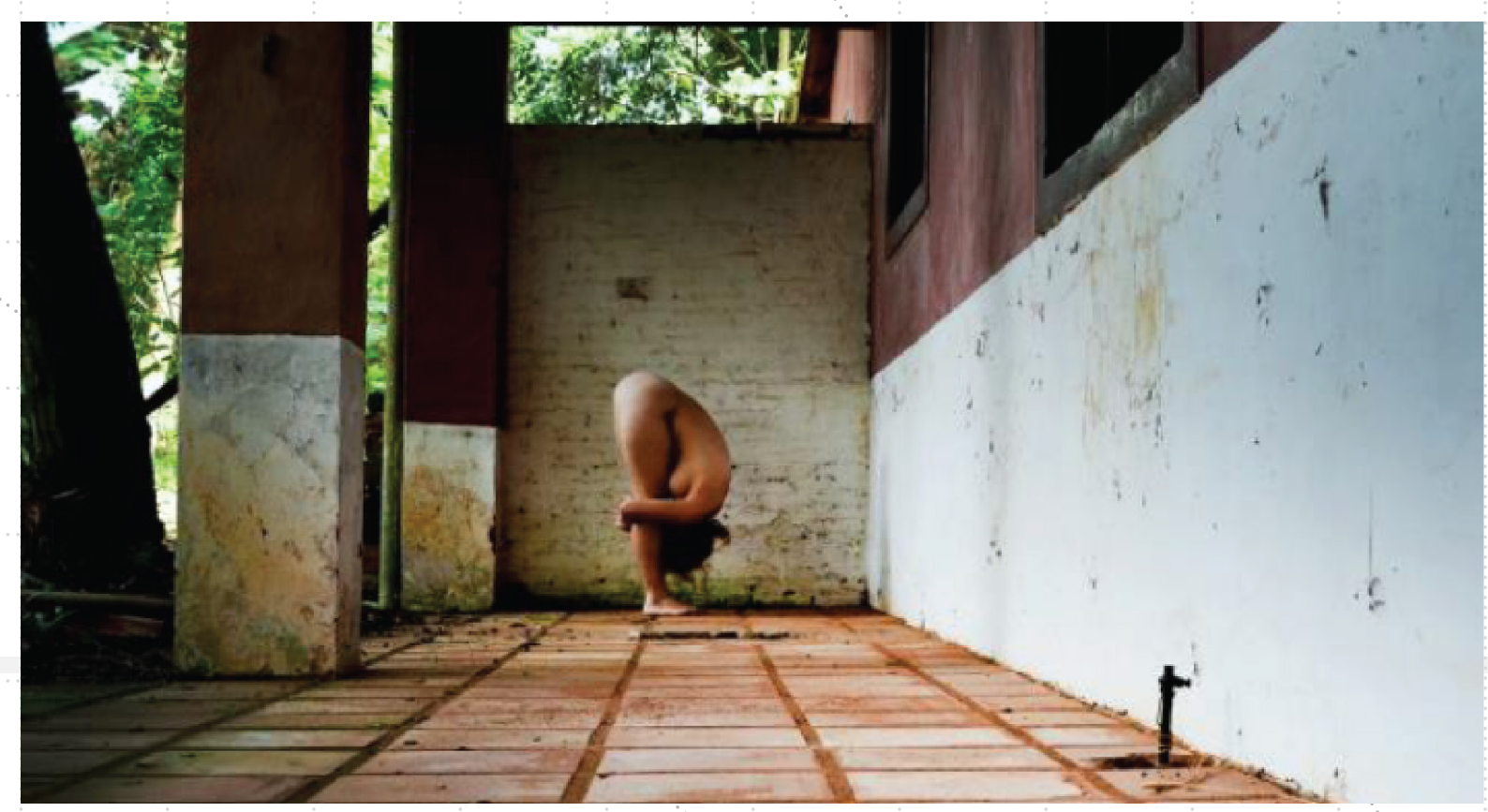

Figura 1 - Diane Sbardelotto. Da série Fotodobragens. 2017, fotografia. Vista da parte externa da Casa do Sol, Campinas-SP. 
Durante a residência artística' na Casa do Sol ${ }^{2}$, realizada em maio de 2017, relacionei os estratos corpóreos or gânicos, subjetivos e semióticos da casa da mulher artista Hilda Hilst. Com o meu corpo de mulher artista trago aqui ações que integraram o primeiro ano de uma pesquisa em desenvolvimento no Mestrado em Educação, linha Filosofias da Diferença, temática Poéticas Transversais, do PPGEdu da UFRGS. A pesquisa hibridiza artes visuais, filosofia e literatura e propõe-se como experimentação de Fotodobragens para continuar o corpo. No corpo mostrado pelas fotografias, há uma delimitação culturalmente assujeitada ao discurso de caráter biológico do corpo feminino, e limitações que prosseguem para muito além dele. Com isso, seguese investigando o quanto desse sujeito advém de práticas e como a mulher artista se constitui como efeito de suas regras, procedimentos, materialidades e outros aspectos de sua arte, sempre aberta a ser reescrita.

Na prática artística, cujo resultado nomeio fotodobragens, endureço escultoricamente meu corpo no registro de uma dobra visível, por um instante, correspondente à programação do temporizador. Isso é também produto para a eternidade. Não se trata de um trabalho restrito ao momento das fotografias, um trabalho restrito ao momento da fotografia, nem da obra como resultado fotográfico, e sim, de uma composição de procedimentos que a antecipam, a motivam e também os que a continuam, tal como a escritura. Meu corpo é fechado, preso em uma fotografia, o que faz também aparecer em opostos disso: as infiltrações, os vazamentos, o inapreensível no corpo, o que não se consegue falar que não se pode conceituar, porque à medida que se aprisiona um corpo, esse é o instante em que ele começa a fugir, "corpo-limite-coitado, de repente te moves" (HILST, 2002, p.23). O corpo se faz outro na tentativa da palavra, retorna diferente da imagem, não condiz, não se deixa apreender, "corpo-limite, contorno repousado ou tenso, até onde o mais eu?" (HILST, 2002, p. 23)

A fotografia, sendo cópia, se faz dobra da imagem do corpo, cópia imprecisa. Fotografo um corpo dobrado. Experimento escrever com ele e com ele fotografar. Fotografá-lo, dobrar, ir-voltar, alternar, perder-ganhar contornos em contorções e rebatimentos que são repetidos mais uma vez e outras, num "eterno retorno" nietzschiano do que não se anula porque difere, do que volta deformado. O movimento do corpo se repete mecanicamente no tempo, a dobra vira vinco, a forma se altera e dá a ver a diferença. Para produzir um corpo múltiplo é preciso dobrar mais uma vez, desdobrar, redobrar.

Se a arte, como literatura para Blanchot, não é mais semelhança e espeltho do mundo, segundo Tatiana Levy, só numa "experiência do fora", o pensamento questiona o pensar essa experiência ultrapassa as ditas "verdades" e pode criar aquilo que Deleuze chama de "plano de imanência". Nesse plano, que se alterna, por dobras, entre liso e estriado, o pensamento está em relação direta com o mundo de fora, não um mundo metafísico, mas um mundo onde se pode poetizar: "o teu corpo existe, porque o meu sempre existiu cantando [...]" (HILST, 2016, p.256).

Na casa de Hilda Hilst, uma poética ganha corpo, um corpo tornase objeto poético, experimenta-se em imagem e texto naquele espaço (Figura 2). Um corpo que aqui se depara com a incerteza da existência de um "eu", que tenta se olhar "de fora", mas para isso precisa questionar-se desde o si. Que enquanto escritura passa a deformar-se para dar-se a ela. Já não o mesmo corpo, porque tudo que é vivo morre o tempo todo, porque entre o mesmo e o diferente há o infinito de gradações contínuas, desde a pele viva até as células que deitam em pó sobre os móveis, que vão ser ainda, depois inspiradas junto com o ar de volta para dentro.
Kazantzákis, do qual as descrições dos mosteiros são influências na arquitetura escolhida para a casa. Lá residiu e trabalhou com poesia, prosa, peças de teatro, além de algumas ilustrações, até falecer em 2004 No espaço,

tombado em 2012 como patrimônio material e imateria permanecem configuração dada pela escritora. Atualmente habitada e sob cuidado da amiga artista e herdeira de seus direitos autorais, Olga Bilenky, a Casa do Sol, transformada em Instituto, recebe em Instituto, recebe residentes para nas quais se pode vivenciapode vivenciá-
la plenamente la plenamente cotidiano de uma colidiano de uma casa, trabalhando cozthinando, dormindo, acessando a biblioteca pessoa 


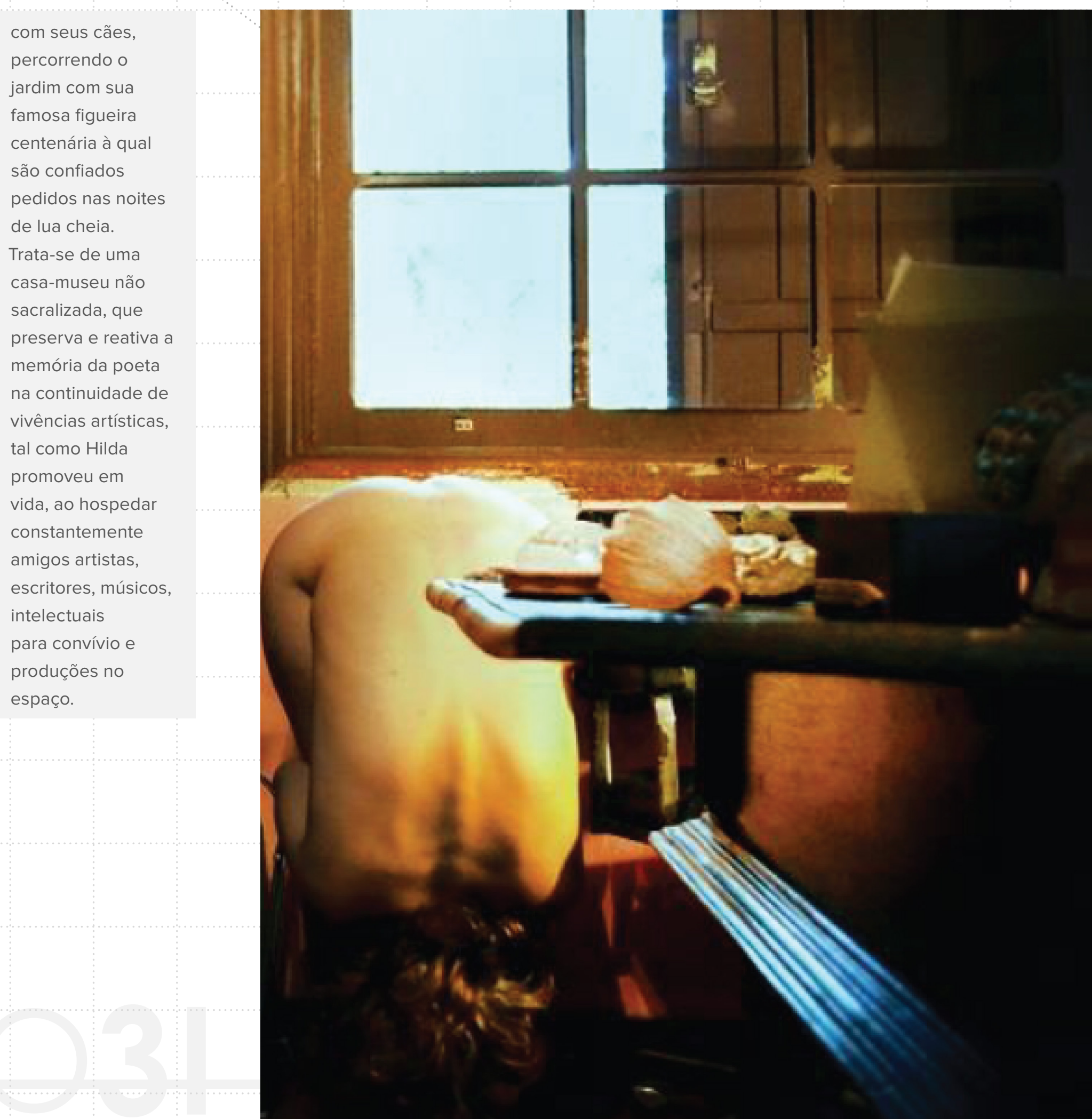

Figura 2-Diane Sbardelotto. Da série Fotodobragens. 2017, fotografia. Escritório onde Hilda Hilst trabalhava.

Casa do Sol, Campinas-SP
Na casa de Hilda Hilst, uma poética ganha corpo, um corpo torna-se objeto poético, experimenta-se em imagem e texto naquele espaço (Figura 2). Um corpo que aqui se depara com a incerteza da existência de um "eu", que tenta se olhar "de fora", mas para isso precisa questionar-se desde o si. Que enquanto escritura passa a deformar-se para dar-se a ela. Já não o mesmo corpo, porque tudo que é vivo morre o tempo todo, porque entre o mesmo e o diferente há o infinito de gradações contínuas, desde a pele viva até as células que deitam em pó sobre os móveis, que vão ser ainda, depois inspiradas junto com o ar de volta para dentro.

As ações performáticas para fotografias vão se compondo com escritos, como o intitulado $E$ o meu corpo existe ${ }^{3}$. Nele, alternam-se imagens e texto poético num ensaio verbo-visual relacionado à dissertação, inspirado na Ode Descontínua e Remota para Flauta e Oboé - De Ariana para Dionísio, onde Hilda alude à história verídica de uma paixão não correspondida. Não só dessa história amorosa, o poema trata de uma condição do feminino na espera e do trabalho de poeta no "enquanto" da paixão. No fora, o corpo e a casa são espaços onde transborda um desejo mais latente quanto menos realizável, que produz poesia na impossibilidade de seu suprimento. Impossibilidades essas, das mais diversas naturezas, que é comum serem diretamente associadas à criação de mulheres artistas em suas biografias, por interpretações de seus trabalhos de arte como outros modos de vida possíveis. A casa, no poema, em simbiose com o corpo da poeta, é protetora de suas ardências que se "transmutam em palavra / Paixão e veemência” (HILST, 2017, p. 257). Não só nesse poema, a proximidade entre a produção acadêmico-poética aqui empreendida e a obra da escritora, está naquilo que é visto em Hilda como "intermidiático", sua "escrita performática" (PÁDUA, 2015) que não termina em si, palavra, que extrapola o espaço do texto, criando a realidade da literatura.
[3] O escrito com as imagens está publicado no blo do Instituto Hilda Hilist, disponivel em: $:<$ http://www hildahilst.com.br/ blog/e-o-meucorpo-existe Acesso em 19/07/2017 
A escrita hilstiana não tem áreas de estabilidade, não é linear, é transversal nos gêneros literários, mistura-se a outras artes. Seu escrever é com a linguagem do corpo desejante, para ser lido com ele. Embora também tenha escrito para dramaturgia, o que faz Hilda performática é a hibridização entre processos e meios, incluindo sua casa dentro de sua obra. Isso pode ser observado também nos caminhos filosóficos que percorrem seus temas, do imaterial e do corpóreo, divino e humano, a morte, a alma, matéria eterna e matéria perecível. Suas personagens questionam o próprio corpo no mundo, suas existências, deslocando-se num "entre" onde esse corpo não tem lugar, ocupa coextensivamente o dentro e o fora de si, da autobiografia, da ficção, da autora e do texto. Saem do, perpassam e continuam o corpo de Hilda-mulher, Hilda-escritora, Hildas-outras.

Nesse processo de entradas, onde se supõe uma linha de separação de corpos produzidos, o externo e interno coexistem menos como espaços e mais como potencialidades de acessar mundos, tal como uma pele que, poderíamos dizer, é tão corpo quanto o mais profundo. "Vontade sim de matar Agda-lacraia só para ver se o que vive dentro dela tem parecença com coisa de fora, verde-azevinhavre, tripa." (HILST, 2002, p. 109).

No procedimento das fotodobragens se instaura um a poética-método. São inevitáveis as hibridizações de linguagens e modalidades no processo. Não se trata apenas de uma concepção contemporânea das artes visuais, mas de uma pesquisa extemporânea em um espaço acadêmico, onde áreas de conhecimento sedimentadas e formatos de apresentação normatizados escapam (Figura 3). Entretanto, apesar dos trabalhos que regulamos corpos que pesquisa me os legitimam enquanto produção validada, fotodobragens traz processos de subjetivação que não se podem reconhecer ou controlar.
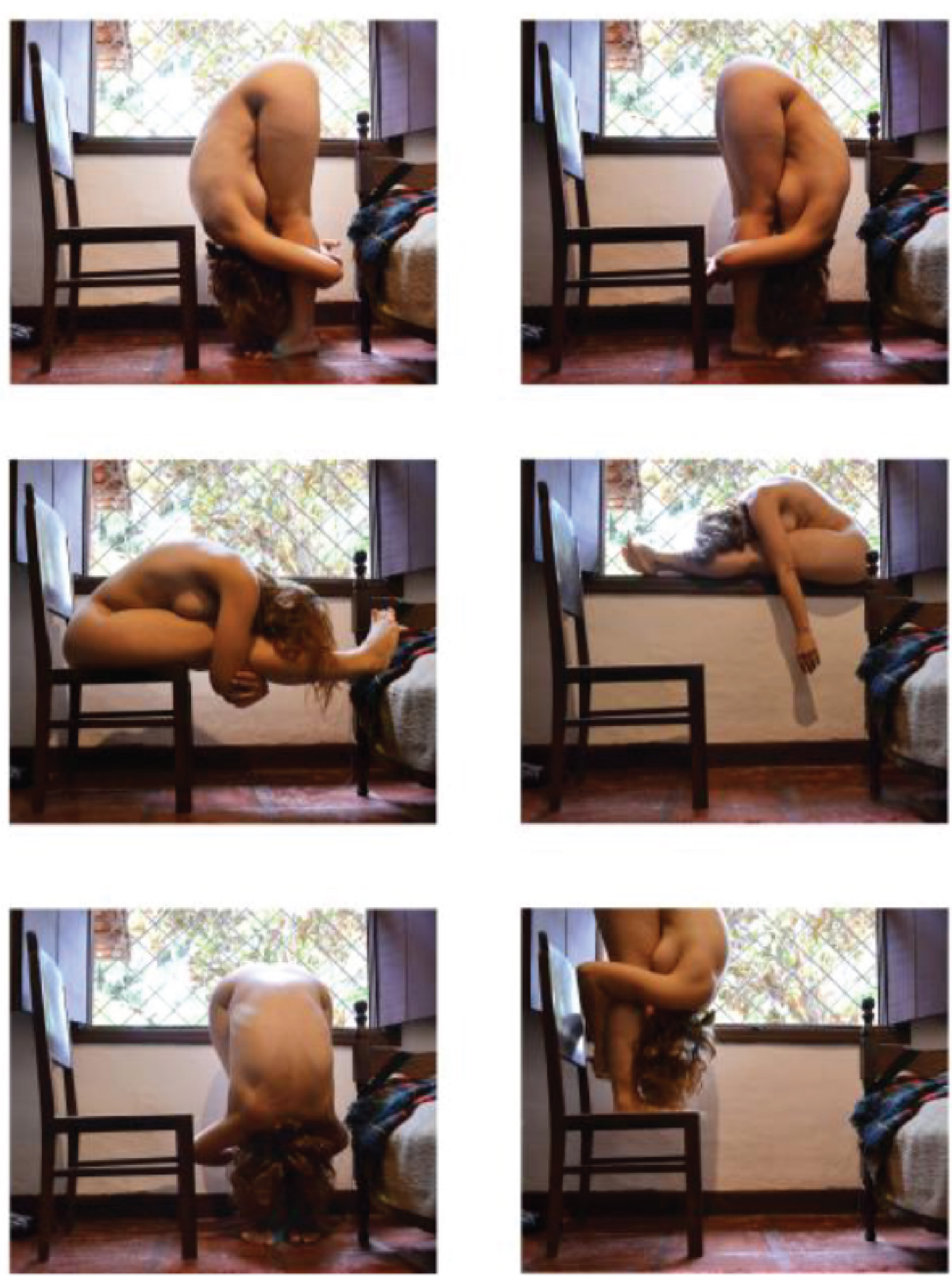

Figura 3-Diane Sbardelotto. Da série Fotodobragens. 2017, fotografia.

Um dos quartos da Casa do Sol, Campinas-SP. 
A realização delas exige mover a cabeça em direção aos pés em ambientes em que me posiciono, corpo-eu do qual ainda não sei, a não ser por relações. São imagens produzidas solitariamente através de temporizador da câmera e de um olhar de fotógrafa-modelo, sujeita a si, observadora e observada. Em alguns ângulos, a identidade, o eu, são deslocados. O corpo fica livre para ser puramente carne, só matéria, nudez esvaziada de sentido, desestruturado, ou de estrutura anatômica incerta, quebradura do humano. Com essa posição de dobra,cujas regras desestabilizam-se na medida em que o trabalho prossegue,exploro diferenciações, espelhamentos, cortes, conexões sempre renovadas, simbioses, alternâncias no ambiente, especialmente voltando-separa o encontro de si próprio, para então encontrar alteridades, ou, com Hilda, um "meu corpo dele" (HILST, 2002, p.26).

Os contornos sinuosos do corpo ora borram as linhas, ora reforçam a dissociação com o ambiente. "[...] sem que tu saibas o teu corpo é crivo" (HILDA, 2002, p. 31). A separação entre corpo e meio não é senão uma zona estratégica de movimentos de diferenciação. Esse movimento constante de trânsito no "entre", devires e alternâncias dos modos dever, viver e produzir mundos, rebate nos versos de Hilda: "Antes de ser mulher/sou inteira poeta" (HILST, 2017, p. 256) nos quais deparo-me com os problemas do "antes de ser mulher", o "ser mulher", o "ser inteira", o "ser inteira poeta". Ser poeta antes? Ser mulher quando? Ter/ser um corpo? Devir as "outras" desse corpo de mulher, corpo de artista, corpo-obra, singularidade. Mais do que responder a essas questões, procuro o que se pode criar com elas. O que esse corpo devolve ao fora, se é que o faz. Sigo numa pesquisa como prática que só pode ser mostrada em sua movimentação, que extrapola a nomeação de "obra de arte", aqui substituída por "prática artística".

PARALELO3!
A dobra do pensamento proposta por Foucault e retomada por Deleuze em meu trabalho poético é também orgânica. Elasticidade conseguida a custo de explorações mecânicas e embates de forças advindos dos diversos trabalhos e lugares pelos quais meu corpo passou potência ou sujeição que na matéria equivalem a alto estado de "ductilidade", deformação que um corpo suporta antes da quebra. Hilda Hilst dizia não querer ser chamada de poetisa porque esta palavra, no feminino, the remetia à fragilidade. Seu trabalho traz uma densidade conceitual de força ativa, perversão na escrita da obscenidade do corpo, tensão entre sagrado e profano, rompimento dos costumes, embates entre realidades da narrativa e da narradora.

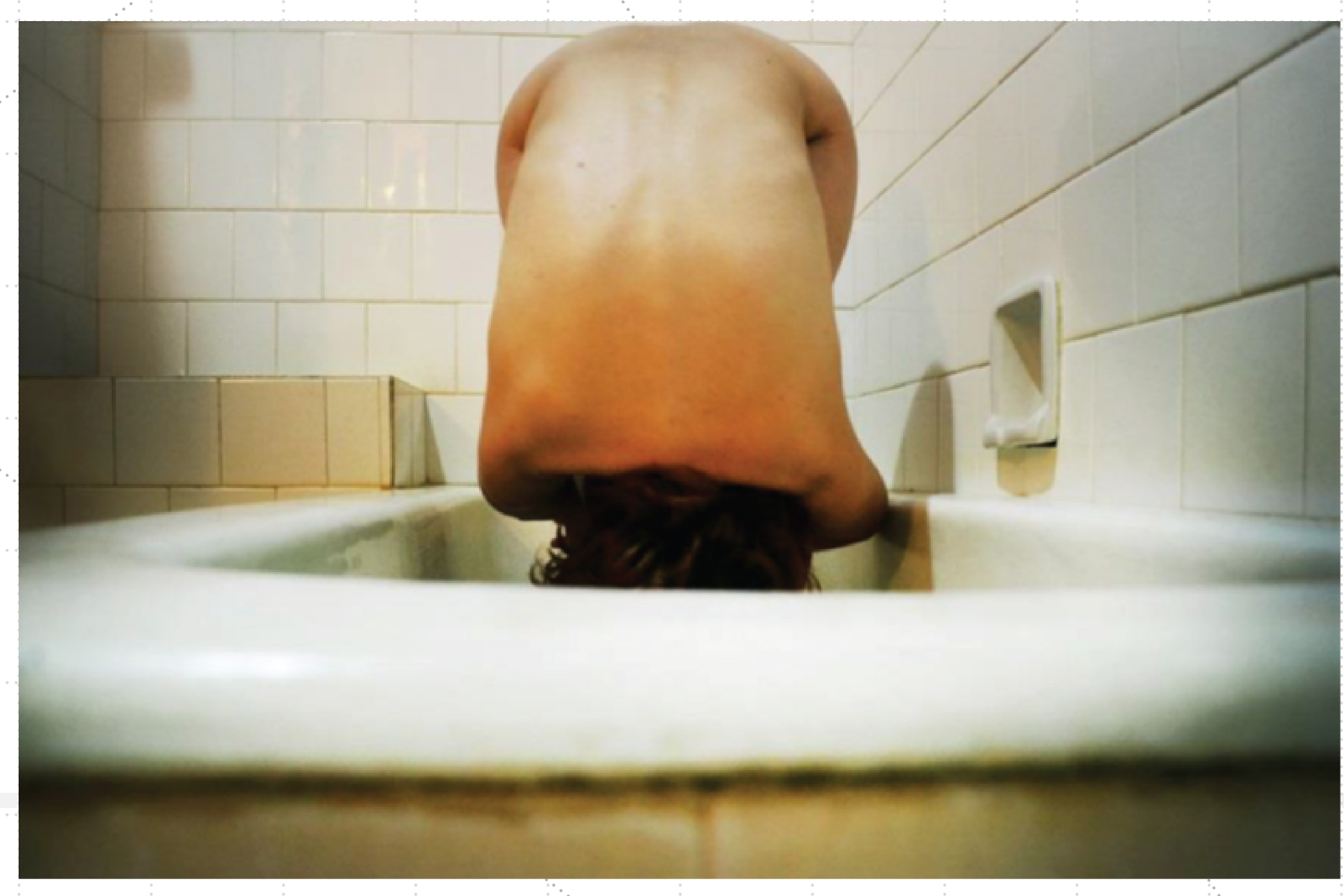

Figura 4 - Diane Sbardelotto. Da série Fotodobragens. 2017, fotografia. Em um dos banheiros da Casa do Sol, Campinas-SP. 
Ao posicionar meu corpo em cômodos da Casa do Sol, essa palavra-lugar trocadilha um "corpo incômodo" (Figura 4). A força de Hilda como artista esbarra em objetos utilitários e espaços totalmente conectados e abordados por ela em seus poemas. Preenchem a "alma em vaziez", que "buscava nomes, tateava cantos, vincos, acariciava dobras" para tentar compreender "isso de vida e morte, esses porquês" (HILDA, 2001, p.05), pensamentos tão luxuosos que meIhor seria fazer um café

Em Obscena Senhora D, há dobras de flacidez, o corpo da personagem tem idade, perturba critérios de "certa" feminilidade, está desgastado, foi muito usado, é interpretado. A própria personagem Hillé se poderia fazer uma referência à hylé, do grego, que significa

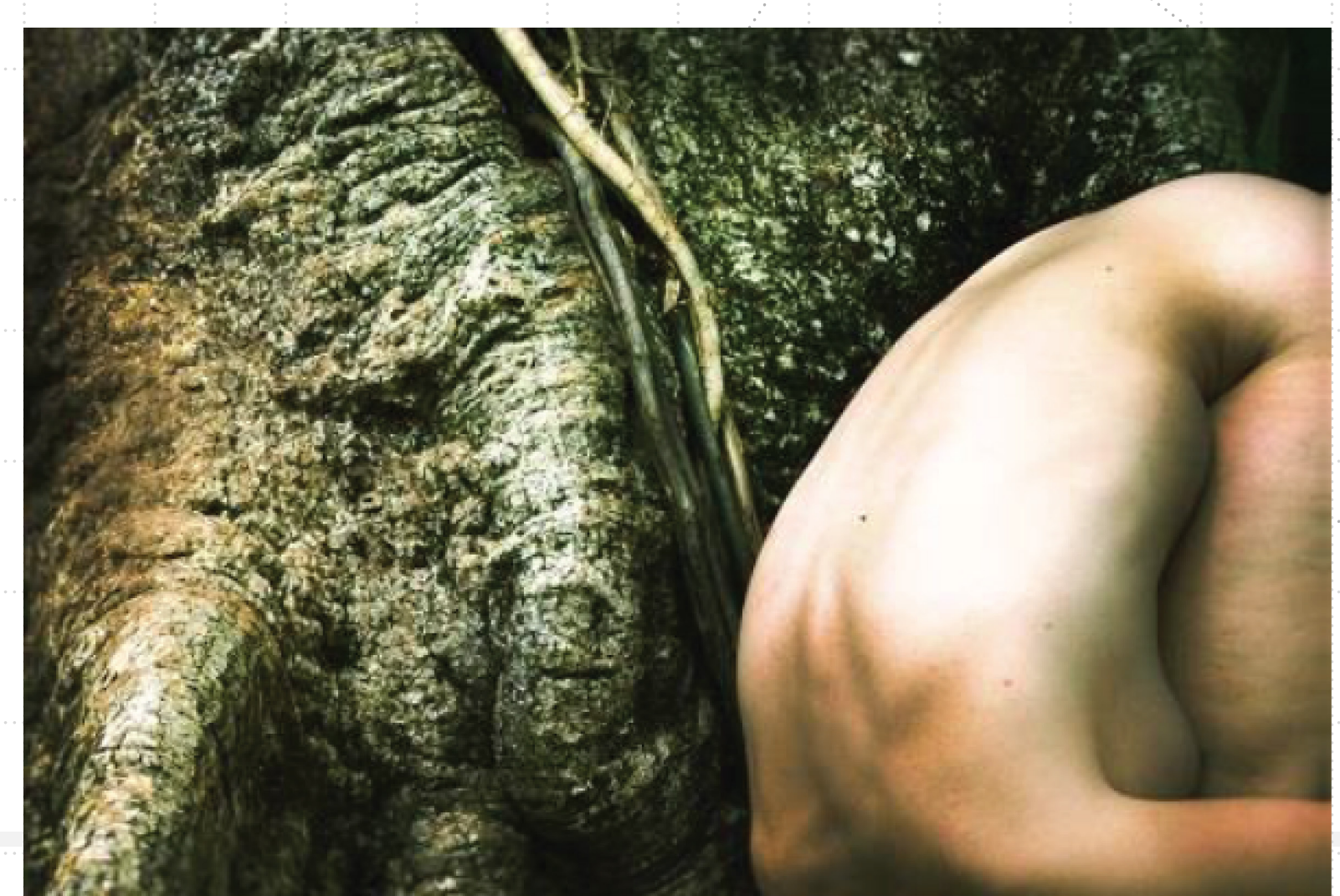

Figura 5 - Diane Sbardelotto. Da série Fotodobragens. 2017, fotografia. Corpo composto com a centenária figueira do jardim da Casa do Sol, Campinas-SP. matéria bruta, indiferenciada, o que a obscenidade da sua crua imagem de mulher idosa faz evidenciar. Produzir junto com Hilda, convoca outros corpos, outras senhoras, como é o caso da Senhora H. sobre a qual Carol Almeida escreve: "você-cavalo, você-cão, você demasiadamente humana e mortalmente comum." (ALMEIDA, 2016).

A personagem Agda, de Kadosh, examina-se, tem um vão nas costas, é corpo-aroma, corpo-procissão, comedora de terra dourada que se toca, que busca dissociações de si como quando diz: "Orto, vamos brincar assim, tu és meu corpo e eu sou teu corpo" (HILST, 2002, p. 108). Ambas as ficções, e outras, como O Caderno Rosa de Lory Lambi, tratam de corpos femininos contra especificidades esperadas, instituídas, diante dos quais Hilda usa metanarrativas, confusão de vozes no texto e erotismo como formas de transgressão Afrontam corpos socialmente comportados, inclusive o corpo do leitor, no qual provoca sensações perturbadoras, e relacionam-se também às contenções do próprio ofício de escrever.

Talvez haja alguma inclinação em pensarmos por separações, na mulher como a real, na artista como a fictícia. Quem morre é a mulher e, então, a artista passa a viver ainda mais. Escrever a partir da premissa $\mathrm{E}$ o meu corpo existe, é aqui afirmar o corpo de mulher artista como um só misturado, dobrado muitas vezes, que perpassa as ficções que criou, realiza-se nelas, existe porque cria.

Essa é uma das questões presente nas especulações sobre muitas escritoras e artistas que se autorreferem em suas obras, especialmente as suicidas, como jovem fotógrafa Francesca Woodman ou como a poeta Sylvia Plath, um dos nomes da biblioteca de Hilda, citada em epígrafes de vários de seus livros. Em A mulher calada, a biógrafa Janete Malcolm comenta a preferência pelos mortos, nossa fascinação pelo estado de inanição daqueles que invejamos porque são mais ativos no erotismo de tirar a própria vida, já que nós “[...] assistimos passivamente 
enquanto a vida nos é tirada pela mortalidade." (MALCOLM, 2012, p. 68)

No trabalho de arte, quando mobilizo meu corpo em fotodobragem, exijo dele grande disponibilidade. Considero-o em todo processo como obra que se desfaz na medida que se faz, semelhante a viver os dias, fazendo-se e desfazendo-se, em uma vida feita de "mortes que precedem o grande limite da própria morte, e que continuam ainda depois" (DELEUZE, 2005, p. 102).

No caso de Hilda, que faleceu por doença, já idosa, em sua imensa vontade de viver conviveu muito de perto com a morte abordando-a em sua vida e obra recorrentemente. Em uma entrevista de 1990 à TV Cultura, ela afirma ironicamente, ou prevê: "acho que vai ser lindo eu na cova, eu famosa". Sua abordagem do corpo foi também buscada além da matéria, o que a levou por vezes a fazer gravações de vozes de existências extracorpóreas no jardim da Casa do Sol.

A casa de Hilda é prova material de que ela existiu, como se precisássemos ver restarem cúmplices, entre eles estão os cães, vidas que estiveram na vida dela. Depois de sua morte, começa o estabelecimento de seu nome. A poeta morta é uma das grandes questões do habitar a Casa do Sol com vivências, ocupá-la, penetrá-la, corporificá-la, contraponto ao tipo de existência sublime que costumamos atribuir às artistas, cujas realidades são as das próprias ficções. Aquelas cuja vida é interpretada na sua obra, cujos esforços do trabalho se sentem na carne. Na Casa do Sol os corpos podem entrar, a existência respira, pesa, sente.

Deleuze e Foucault, a partir de Nietzsche, apontam para uma estética da "vida como obra de arte", pensada também como uma ética. Deleuze diz que o estilo de um escritor é sempre também um "estilo de vida, a invenção de uma possibilidade de vida, de um modo de existência” (DELEUZE, 1992, p. 126). No estilo de Hilda Hilst, a escrita incorre muitas vezes nas junções de palavras. Aqui, ao seu esti- lo, penso Hilda-corpo, um corpo-todo, corpo-teto, todo-seu, meu-eu, debaixo do qual a chuva não cai. O próprio corpo é que chove, em lágrimas, excreções, é um corpo que se liquefaz. Que foi vomitado pela vida, que não escolhe nascer, mas que pode escolher não gerar

Hilda-mulher teve muitas vezes que explicar sua decisão de não ter filhos. O pai poeta que passou grande parte da vida internado por esquizofrenia, inspirava-Ihe temor de um outro tipo de repetição, a dos genes da doença que intercalam uma geração. Gerar, para ela, esteve associado a outras formas de vidas, como seus cães, que the eram seres de cuidado. "O cão é também uma coisa que está dentro dela" (HILST, 2002, p. 108) ou "cão-de-pedra" (entre os muitos nomes usados por ela para se referir a Deus). Há menções da palavra cão no conto Agda, personagem esta que reflete também sobre a maternidade: "nunca tive filhos, é por isso que eles são bonitos [...]" (HILST, 2002, p.22)

Entre muitas questões do feminino em sua obra, foi especialmente nos seus comportamentos acusados de uma agressividade socialmente escandalosa, tomado como responsável por diminuir o que sua geração esperava da feminilidade. Neste fora do feminino me localizei em seu espaço, criando o meu, dentro da casa. Nossa casa-corpo, na qual percebi, pela primeira vez, que a dobra que ali realizava para meu trabalho estava localizada em meu útero. Dobrar o corpo ao meio era esmagá-lo, tentar vincar essa parte vazia, mole, moldável.

O corpo humano, paradoxalmente expelido pelo ambiente, em performance é re-adicionado a ele (Figura 6). Dissociações de origem, como a entre corpo e terra, junto à dobra pensada como retorno, criaram caminhos para pensar que o corpo morto voltará a misturar-se com o chão, junto a casa. Além de um teto, parede, invólucro, como pensou Virgínia Woolf em Um teto todo seu, nos deparamos com a 


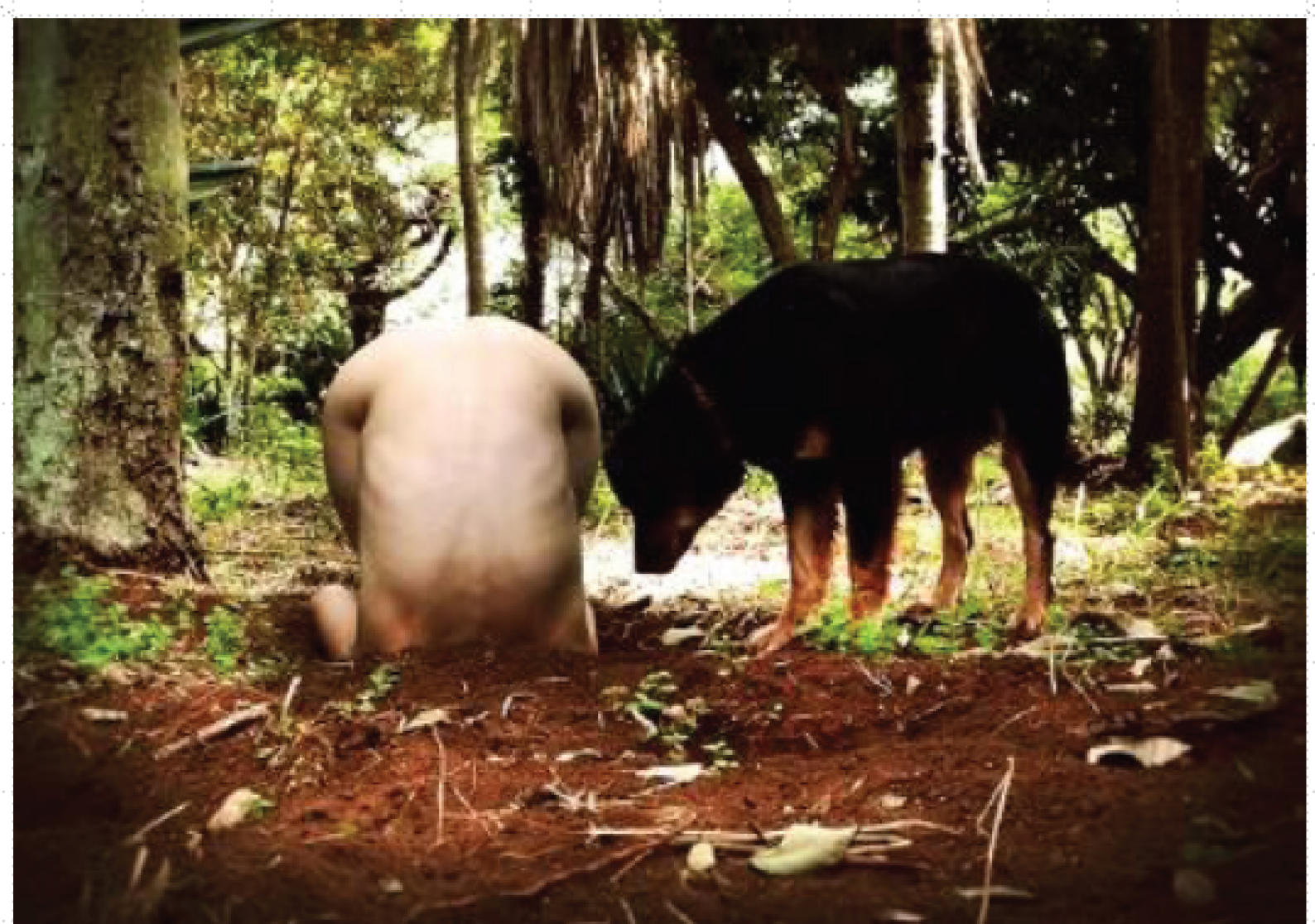

Figura 6 - Diane Sbardelotto. Da série Fotodobragens. 2017, fotografia.

Pátio da Casa do Sol, buracos cavados pelos cães, e, ao lado, a cachorra

Balalaica, Campinas-SP

necessidade de uma localização, ainda que provisória, sempre em descontinuidades. Algo como um pertencimento, que inquieta desde a questão sobre se somos nosso corpo, ou se estamos nele, sobre a obscuridade do espírito que põe a exigência de termos um, questão tratada por Deleuze em A dobra: Leibniz e o Barroco, em estudo nessa pesquisa. Além destes, o lugar social no meio artístico também é experimentado e pensado. Esse trabalho tem permitido observar as coisas pelas quais a experiência com o corpo é mediada, coisas e palavras que nos separam ou nos fazem acessar o corpo, que incorporamos ou subtraímos nele.

Residir na Casa do Sol é uma experiência marcante para uma pesquisa em artes visuais porque entra-se com o corpo, esse, no qual, por convenção nos reconhecemos humanas, por generalização fêmeas, e moramos quase sempre sem caber. Penetrar essa casa é acontecimento que escreve e conserva afectos e perceptos pela pele adentro. A casa é como um deslimite entre entrada e saída, passagem. A experiência, compartilhada com outras mulheres, também se encontrou com a mulher que reside na casa, suscitando-nos, enquanto artistas e residentes, um tomar a si como objeto de pesquisa, uma interação com a poética e vida de Hilda. A residência permitenos viver a obra de Hilda e nos estranhar pelo corpo, talvez na única maneira possível de tratar de subjetivações, essas forças que não se consegue medir senão a partir das próprias práticas de si.

\section{REFERÊNCIAS}

ALMEIDA, Carol. Estimada Senhora H. Disponível em: $<$ http://www. suplementopernambuco.com.br/edi\% $\mathrm{C} 3 \% \mathrm{~A} 7 \% \mathrm{C}_{3} \% \mathrm{~B}$ 5es-anteriores/77capa/1387-estimada-senhora-h.html. Acesso em 15/07/2017>.

DELEUZE, Gilles. A dobra: Leibniz e o barroco. Trad. Luiz B. L. Orlandi. $6^{a}$ Ed.Campinas Papirus, 2012

DELEUZE, Gilles. As dobras ou o lado de dentro do pensamento. In: Foucault. São Paulo: Brasiliense, 2005

DELEUZE, Gilles. Conversações. São Paulo: Ed. 34, 1992.

HILST, Hilda. Da Poesia. São Paulo: Companhia das Letras, 2017

HILST, Hilda. Entrevista concedida à TV Cultura, por ocasião do lançamento de $O$ caderno Rosa de Lori Lamby, em 1990. Disponivel em: https://www.youtube.com/ watch?v=5yeFhO4G2OQ. Acesso em 16/07/2017. 


\section{HILST, Hilda. A Obscena Senhora D. São Paulo: Globo, 2001}

HILST, Hilda. Kadosh. São Paulo: Globo, 2002.

LEVY, Tatiana. Salem. A experiência do fora: Blanchot, Foucault e Deleuze. Rio de Janeiro: Civilização Brasileira, 2011.

MALCOLM, Janete. A mulher calada: Sylvia Plath, Ted Hughes e os limites da biografia. São Paulo: Companhia das Letras, 2012

PÁDUA, Arethuza lemini de. A Linguagem do Corpo na Obra de Hilda Hilst:"Agda"

e a Obsceno Senhor D. Dissertação apresentada ao curso de Pós-Gradugça" e a Obscena Senhora D. Dissertação apresentada ao curso de Pós-Graduação

ente, 2015

WOOLF, Virgínia. Um teto todo seu. São Paulo: Tordesilhas; 2014. 